\title{
Mediatization of religion in "texting culture": self-help religion and the shifting of religious authority
}

\author{
Moch Fakhruroji
}

Sunan Gunung Djati State Islamic University, Bandung

E-mail:moch.fakhruroji@uinsgd.ac.id

DOI: $10.18326 /$ ijims.v5i2.231-254

\begin{abstract}
This research is the study of SMS Tauhiid phenomena as a religious practice in the context of media culture. SMS Tauhiid service enables its customer to access religious messages through SMS which is in particular contexts could potentially bring new patterns of religious practice. This article uses the mediatization concept dealing with media studies and political economy as well. I argue that tausiah as (Islamic) religious communication practice have transformed into a new pattern that caused by the accomodative actions that has taken by the religious leaders and actors against media logics. On the one hand, this phenomenon has opened a new phase in disseminating religious messages, however on the other hand mediatization of religion has potential in causing a shift in the role of religious leaders as the religious authorities.

Penelitian ini merupakan studi tentang fenomena SMS Tauhiid sebagai bentuk praktik agama dalam konteks budaya media. SMS Tauhiid memungkinkan setiap pelanggan dapat mengakses nasihat agama melalui SMS yang dalam konteks tertentu berpotensi memunculkan pola-pola baru dalam beragama. Artikel ini menggunakan pendekatan konsep mediatisasi yang memiliki kaitan erat dengan disiplin media studies dan ekonomi politik. Saya berargumen
\end{abstract}


bahwa tausiah sebagai praktik komunikasi agama (Islam) telah mengalami transformasi kedalam bentuk baru disebabkan tindakan akomodatif yang dilakukan para tokoh dan aktor agama terhadap logika media. Di satu sisi, fenomena ini telah membuka babak baru bagi proses penyebaran pesan-pesan agama, namun di sisi lain mediatisasi berpeluang menyebabkan pergeseran peran tokoh agama sebagai pihak yang memiliki otoritas sumber informasi agama.

Keywords: SMS Tauhiid; Tausiah; Media logics; Texting culture; Mediatization

\section{Introduction}

The latest information and communication technology have led to the new cultural pattern so-called media culture that was born by images, sounds and lenses in generating patterns of everyday life, dominated the spare time, (re)shaping the political views and social attitudes and even provide material in establishing personal identity. ${ }^{1}$ Media culture helped to shape the common world-view and its values. Furthermore, it defines which is good or bad, positive or negative, immoral or barbaric. In more practical terms, media culture is described as media-saturated culture phenomenon, or even a culture that is emerged by certain media technology. Media culture is generally often described as a phenomenon of how media changes, structures, and even determines the direction of our everyday life, including in religious practices.

Although discussions about relationship between religion and the media often reflected some issues about their nature and how they are interconnected, religion is still widely seen as a domain of human experience that is separated from media. Religious meaning was emerged and formed based on what they believe while the media only seen as a chan-

${ }^{1}$ D. Kellner, Budaya Media: Cultural Studies, Identitas dan Politik antara Modern dan Postmodern, Translated into Bahasa Indonesia by Galih Bondan Rambatan, Yogyakarta: Jalasutra, 2010, 1. 
nel to deliver religious meanings to the public. This understanding implies that religious communication is considered to be effective if its messages are able to influence the audience behavior. ${ }^{2}$

However further developments showed that media has become part of the wider process of social mediation that led to understanding that media not only as a channel in conveying messages but also has its own characteristics. The convergence of these factors has implied to the improvement of understanding about the concept of media and began to change the understanding about the relations of media and religion. This cultural perspective has moved its focus from the effects of media on society or culture as a mediated phenomenon toward how media contribute to social life.

Therefore, Horsfield ${ }^{3}$ confirms that media studies today are no longer carried out separately from other entities, but as part of the dynamics of society itself. It means that mediated reality not only consist of the media of mass communication technology but a total process of mediation in whole life. Since it is interconnected in the cultural process, media are not only conceived as instrument in conducting fixed message but also as a site where construction, negotiation, and the reconstruction of the meaning of culture conducted in ongoing process of maintaining and changing the particular structure, relationships, meanings and values of a culture. Furthermore, this phenomenon is known as mediatization.

As an alternative paradigm of media theory, mediatization assumes that the media is not outside the community, but become a part of the fabric of society itself. Media has been integrated into the workings in almost all types of social institutions at the same time have a stake in

${ }^{2}$ P. Horsfield, "Media" in David Morgan (ed.), Keywords in Religion, Media and Culture, London: Routledge, 2008, 112.

${ }^{3}$ P. Horsfield, "Media"..., 113. 
society as in communication in a private setting. Through this social integration process media provide influence and are involved in the transformation of social institutions, including religion. ${ }^{4}$

One type of popular and growing media in the socio-cultural life is mobile phone with SMS (Short Message Services) as one of its fundamental features. SMS much lauded for its ability to form collectivity, or even to establish identity and national policy, as revealed in the latest research of Berendegt and Pertierra about coup in the Philippines who dropped Estrada as president through SmartMob that triggered by SMS broadcast to demonstrations. ${ }^{5}$

As a relatively new phenomenon, research on socio-cultural dimension of mobile phone and its features including the SMS, started to emerge in the 1990s. Among of them are researches on community experiences on mobile phones as new technology. ${ }^{6}$ As the growing number of users and the expansion of its impact, another research theme consistent growth in the mobile phone market growth of lifestyle. ${ }^{7}$ Meanwhile Fortunati ${ }^{8}$

${ }^{4}$ S. Hjarvard "The Mediatisation of Religion: Theorising religion, media and social change," Culture and Religion, Vol 12, No. 2 (June, 2011), 21-22.

${ }^{5}$ B. Barendegt and R. Pertierra, "Supernatural Mobile Communication in the Philippines and Indonesia" in James E. Katz. Handbook of Mobile Communication Studies, Massachusetts: MIT Press, 2008.

${ }^{6} \mathrm{~J}$. Wood, Cellphones on the Clapham Omnibus: The Lead-Up to a Cellular Mass Market, SPRU CICT Report No. 11, University of Sussex: Falmer, November, 1993. See also L. Rakow, in V. Navarro, "Remote Mothering and the Parallel Shift: Women Meet the Cellular Phone”, Critical Studies in Mass Communication, 10/2 (1993) and De Gournay, C., Tarrius, A., and Missaoui, L. "The Structure of Communication Usage of Travelling Managers", in Haddon, L. (ed.), Communications on the Move: The Experience of Mobile Telephony in the 1990s, COST 248 Report, Farsta, Sweden: Telia AB., 1997.

${ }^{7}$ M. Christoffersen, "Mobile Telephony in Denmark: From Fishermen to Businessmen: Social Aspects of the NMT-System", Les Usages Sociaux de la Téléphonie Mobile en Scandinavie, CNET/IDATE seminar, Institut Finlandais, Paris, 30 January (1992).

${ }^{8}$ L. Fortunati, "The Ambiguous Image of the Mobile Phone", in L. Haddon (ed.), Communications on the Move: The Experience of Mobile Telephony in the 1990s, COST 248 Report, Farsta, Sweden: Telia, 1977. 
reveals the function of mobile phone began to function as a reflection of the owner's identity. Discussion about the theme more widespread and in diverse perspectives, for example, aspects such as; cyberspace or cellular, ${ }^{9}$ cellular phones and the creation of a more nuanced coordination, ${ }^{10}$ as well as cell phones began to act as social control and family, ${ }^{11}$ and the study of cellular phones has also touched other social aspects, including the aspects of politics, ${ }^{12}$ culture, ${ }^{13}$ and religion. ${ }^{14}$

Meanwhile, specific research on the relationship of mobile phones with religion, among others, research on relationship of Islamic applications on mobile phones with religious expression ${ }^{15}$ and analysis of advertisements on two cellular operators Indonesia were launched "Islamic" bundling. ${ }^{16}$ Furthermore, specific research on mediatization of religion such as; mediatization religion and religious practices, ${ }^{17}$ the implication

\footnotetext{
${ }^{9}$ L. Fortunati, "The Ambiguous Image of the Mobile Phone", in L. Haddon (ed.), Communications on the Move: The Experience of Mobile Telephony in the 1990s, COST 248 Report, Farsta, Sweden: Telia, 1977. see also H. Geser, "Towards a Sociological Theory of the Mobile Phone", Sociology in Switzerland: Sociology of the Mobile Phone, online publication, Zürich, May 2004 (Release 3.0) <http://socio.ch/mobile/ t_geser1.pdf>

${ }^{10}$ L. Haddon, Old and New Forms of Communication: E-mail and Mobile Telephony: A report for British Telecom, Martlesham: British Telecom, 2000. See also R. Ling and B. Yttri, "Hypercoordination via mobile phones in Norway", in Katz, J. and Aakhus, R. (eds.), Perpetual Contact: Mobile Communication, Private Talk, Public Performance, Cambridge: Cambridge University Press, 2004.

${ }^{11}$ L. Haddon, Old and New Forms of Communication: E-mail and Mobile Telephony: A report for British Telecom, Martlesham: British Telecom, 2000.

${ }^{12}$ M. Rao and M. Desai, "Boom in India: Mobile Media and Social Consequences", in James E. Katz, Handbook of Mobile Communication Studies, Massachusetts: MIT Press, 2008.

${ }^{13}$ R. Ling, The Mobile Connection: The Cell Phone's Impact on Society, San Francisco: Elsevier, 2004.

${ }^{14}$ G.R. Bunt, "Surfing the App Souq: Islamic Applications for Mobile Devices", Cyber Orient, Vol. 4, Issue 1 (2010). See also Suryanto, "Iklan dan Komodifikasi Agama”, Tesis, Yogyakarta: Universitas Gadjah Mada, 2011.

${ }^{15}$ G.R. Bunt, "Surfing the App Souq: Islamic Applications for Mobile Devices, in Cyber Orient, Vol. 4, Issue 1 (2010).

${ }^{16}$ Suryanto, "Iklan dan Komodifikasi Agama", Tesis, Yogyakarta: Universitas Gadjah Mada, 2011.

${ }^{17}$ S.M. Hoover, Religion in the Media Age, New York: Routledge, 2006.
} 
of mediatization of religion to the forms of religion, ${ }^{18}$ and mediatization of religion and the change of sense of spirituality among Danish youth. ${ }^{19}$

This paper will generally reveal the phenomenon of mediatization of religion in the context of text-messaging culture. By taking SMS Tauhiid as the case, this paper describes SMS Tauhiid as a phenomenon of mediatized religion and its implications with its various characteristics have some potential to change religion in more self-help and provide a challenge to the religious authority caused by the dominance of the media logics.

\section{Religious texting as mediatized religion}

Theoretical discussions about the SMS usage in delivering religious messages seem to be started with the discussion about mobile phones. In contrast to other media, mobile phones have a number of advantages, especially in terms of its ability to create some new interactions. Ling revealed that mobile communication through mobile phone is able to strengthen friendships and family communication. Mobile phones could also create better relations in the personal space, even if compared with other computer-based interpersonal media such as e-mail and instant messaging. ${ }^{20}$

The spread of mobile phones and other wireless devices have influenced our lives and social relations. The compactness of mobile phone allows a person to be more flexible on business and professional level as

${ }^{18}$ S.Hjarvard, "The Mediatisation of Religion: Theorising religion, media and social change", Culture and Religion, Vol 12, No. 2 (June, 2011): 21-22.

${ }^{19}$ L.N. Petersen, "Renegotiating religious imaginations through transformations of "banal religion" in Supernatural”, Transformative Works and Cultures, No. 4 (2010). See also her other works in L.N. Petersen, "Understanding superpowers in contemporary television fiction”, Northern Lights: Film and Media Studies Yearbook, Vol. 6 (2011), 91-106.

${ }^{20}$ R. Ling, New Tech, New Ties: How Mobile Communication is Reshaping Social Cohesion, Cambridge, Massachusetts: MIT Press, 2008, 3. 
well as in personal life and family. Not only that, Katz and Aakhus outlined that mobile phones and other mobile technologies are also affected on how people interact in face-to-face by highlighted three things. First, they see mobile phones as technologies that affect human life. Secondly, they see mobile phones as technology that can shape and decorate life due to the newness of the mobile phone enables us to find aspects of the communication process that may escape our attention. Third, the mobile phone has been modified, strengthened and replaced previous patterns of communication. ${ }^{21}$

In order to seek relationship between technology and culture in the case of mobile phones, it may be compared with the notion of virtuality and cyberspace that appeared in internet studies. By its various characters, mobile phones have similar potential in its ability to create a virtual environment and cyberspace. Through mobile phones, we have unlimited access to friends, family members and so on. Mobile phones seem to provide a virtual space where everyone is able to utilize the facilities.

In Ling analysis, one of the effects of mobile phone is the emergence of "hyper-coordination" 22 which can be seen in various phenomena. For example, the uses of mobile phones expressively provide communication that more emotionally. We can conduct a conversation with the various alternatives; chat, SMS, and the messages that are general, private, or even secret context. Another aspect of hyper-coordination is in-group discussion and agreement on how to represent themselves through mobile phones, for example, using SMS is only appropriate in certain situations and reflect the closeness between users.

\footnotetext{
${ }^{21}$ J. Katz and M. Aakhus (ed.), Perpetual Contact: Mobile Communication, Private Talk, Public Performance, Cambridge: Cambridge University Press, 2004, 4.

${ }^{22}$ R. Ling and B. Yttri, 'Hyper-coordination via mobile phones in Norway,' in Katz, J. and Aakhus, R. (eds.), Perpetual Contact: Mobile Communication, Private Talk, Public Performance, Cambridge: Cambridge University Press, 2004, 139.
} 
In his other works, Ling has also explored how contact is mediated by mobile phones can also be seen in the context of ritual interaction or daily habits. The way we greet each other, share stories, and the way we use mobile phones to organize daily life indicates that the rituals of interaction can be done through interactive media. Furthermore, there is various form of interaction that seems to appear only by mobile phone. ${ }^{23}$

Furthermore, mobile phones are more individual than the traditional or fixed phones. With traditional phones, we call home or place, while via mobile phone we call personal. When we send a message to certain number, we assume that the message will reach the person we are headed at the time, regardless where the person is. Mobile phone and SMS have allowed us to do this kind of interaction. Specifically, even SMS enables interaction that is asynchronous in the sense that the sender is not bound by the recipient's full attention to communicate and vice versa. Furthermore, the sender can develop and update the message before they push the send button.

SMS is not only viewed by the perspective of the individual, but also can be viewed in the perspective of the group. Therefore, SMS occupy an important role in shaping the interaction among individuals. Practically, SMS helps coordinate, inform and generally maintain our social contact. Overall, SMS has been a real medium to connect us to social networks in ways to maintain "background awareness" as occurred in our social space. ${ }^{24}$

The use of SMS feature in daily communication has become a ritual of our daily life. The nature of SMS that are personal, its ability in creating the hyper-coordination and asynchronous in particular has become our daily habit. Everyday we produce and consume text messages by send-

${ }^{23}$ R. Ling, New Tech, New Ties..., 3.

${ }^{24}$ Ito, et al. "Mobile phones, Japanese youth and the re-placement of social contact," in Ling R. dan Pedersen P.E. (ed.) Mobile Communication: Re-negotiation of the Social Sphere, London: Springer, 2005. 
ing and reading SMS so it has become a new kind of culture in our lives or can be expressed through the concept of "texting culture." The term of texting culture in this discussion refers to our habit of using SMS that can be integrated with other aspects of our everyday social practice. It has become one of the socio-cultural practices that align with other practices.

As a culture, the use of SMS is also linked to a series of meanings and practices of different cultures. As well as the Sony Walkman in exposure of du Gay et $\mathrm{a}^{25}$ which have a distinctive "culture" by developing a set of meanings and practices of different cultures. It connects a series of social practices (such as listening music while traveling on the train). It became cultural due to contact with; certain groups of people (youths or music lovers, for example); certain places (cities, outdoors) all of whom have given identity. It is also cultural as they often appear and represented in the visual language and our communication media. Then, the image of Sony Walkman that is sleek, high-tech and functional design has become a kind of metaphor that represents the technological culture or modernadvanced way of life in different ways. Meanings, practices, image and identity of this makes us to put the Sony Walkman as cultural artifact.

In the same way, the SMS technology was actually having a specific distinctive "culture". For example, we could send SMS messages while doing other activities such as shopping, lunch, working in the office, play, relax in the park, learning at home, all of which are part of our lives everyday so it has changed our meaning of leisure time, SMS is also cultural because it has opportunity to create new communication patterns, such as its asynchronous nature, the emergence of emoticons and textbased symbols. In addition, SMS is often seen as a way of communicating that is more private than the calling features. Every meaning, practices,

${ }^{25}$ Du Gay et al., Doing Cultural Studies: The Story of the Sony Walkman, London: SAGE Publications, 1997. 
image and confirms the identity of the SMS as one culture.

SMS capability in creating hyper-coordination has also implied to socioreligious interaction. However, it should be noted that the religions in this context is understood as a social practice. Theoretically, Roof uses the term "lived religion" to describe the idea of religion as a social practice. ${ }^{26}$ This term presents a concept that can be identified through three important aspects, namely; scripture that used as a reference, practice, or the means by which people relate and put themselves in the frame of reference that is symbolic; and person's ability to actively bond in the religion domain that they want to create.

Generally, this perspective focuses on three interrelated parts. First, the issue of symbols or sacred texts that appear in the media environment, or can be referred to as "symbolic inventory" in which a person obtains a religious or spiritual significance; second, consumption practices, interaction and articulation through which meanings are accessed, understood and used; and third, focused on individual experience in performing the act of consumption and acquired religious significance. The presence of religious messages as SMS contents are not only describes the phenomenon of new religious practice by using the media, but also describes the media coverage of religion that could potentially bring some problems that are new. In order to understand this phenomenon, I consider using the approach of mediatization concept.

Mediatization is a concept dealing with socio-cultural changes associated with the intensification of media. As a realm of interdisciplinary research that are relatively new, mediatization studies had invited the semantic debate. Some parties use the term mediation while describing mediatization concept, such as; Martin-Barbero, Silverstone, Stewart M.

${ }^{26}$ S.M. Hoover, Religion in the..., 39. 
Hoover and others. Martin-Barbero ${ }^{27}$ for example, used term mediation to explain the process of domination and hegemony of media over culture. Meanwhile, Silverstone ${ }^{28}$ used the term mediation as a concept that describes the transformation of society and culture by the media. Similarly, Hoover ${ }^{29}$ used the term mediation when describing the relationship built between religion-and other aspects of culture-in the sphere of culture which are influenced by the media.

However, this semantic debate is no longer important because basically the relevance of media with social practices in daily life are in a long term as on-going process. ${ }^{30}$ Therefore, the concept of mediatization is actually more than just a label for the phenomenon of the improvement media effects on society, but also on how the media relates to aspects of other social and cultural life, as can be found in the central theories in sociology.

Stig Hjarvard noted that mediatization can be characterized by the development of the media on two sides. First, the media has developed into institution that is autonomous and independent in society. Secondly, when the media is emerging as an independent institution in society, it became more integrated in the working area of other social institutions. This implies that in the next stage, media becomes a natural component of everyday life such as education, politics, family life and religion. ${ }^{31}$

${ }^{27}$ J. Martin-Barbero, Communication, Culture and Hegemony: From Media to Mediations, translated by Elizabeth Fox and Robert A. White, London: SAGE Publications, 1993.

${ }^{28}$ R. Silverstone, Media and Morality: On the Rise of the Mediapolis, Cambridge: Polity Press, 2007.

29 S.M. Hoover and L.S. Clark (ed.), Practicing Religion in the Age of the Media: Explorations in Media, Religion, and Culture, New York: Columbia University Press, 2002. See also S.M. Hoover, Religion in the Media Age, New York: Routledge, 2006.

${ }^{30}$ F. Krotz, "Mediatization: A Concept with Which to Grasp Media and Societal Change" in Knut Lundby, Mediatization: Concept, Changes, Consequences, New York: Peter Lang Publishing, 2009.

${ }^{31}$ S.Hjarvard, "The Mediatisation of Religion: Theorising religion, media and social change", Culture and Religion, Vol 12, No. 2 (June, 2011), 122-123. 
Hjarvard revealed three forms of mediatized religion, namely (1) religious media, (2) journalism on religion and (3) banal religion. ${ }^{32}$ First, religious media shows the relationship between religion and media which assumed religion as a subject so media role is more active as a medium. It can be seen from the dominant religious roles both as an institution, actor (figure) as well as texts in the context of religious communication. Nevertheless, this does not mean that religion can just show up in the media because religion must accommodate the media logics which potentially implied for the shift of religion as the content of communications.

Second, mediatized religion is also emerge in journalism on religion. Because journalism has had a certain practice and is more concerned with public representation through news coverage, then the institution or religious leaders should accommodate the demand of journalism in order to gain access to the public media. As the most prominent forms of mediatized religion, journalism on religion has potential to reduce the ability of institutions and religious leaders in explaining and framing religious issues in public spaces.

Third, mediatized religion can also showed in the form of banal religion. This typology demonstrates the ability of the media in presenting a number of symbols and actions that implicitly can actually strengthen the presence of religion in culture and society, but in a different way. Banalization of religion conducted by the media is done by representing various rituals and religious symbols, for example ustadz (religious teachers), Muslim clothing, accessories and so on, but combined in new ways and with some meaning those are relatively independent. Religious symbols presented by media no longer refers to the existing meaning but reconstructed in such way to meet the media interests.

32 S.Hjarvard, "The Mediatisation of Religion”..., 122-123. 
Therefore, by using the Hjarvard's model above, the emergence of religious messages via SMS can be assumed as a form of mediatized religion. Similar to the religion that emerged in other various forms of media, religion in the SMS content can emerge as a religious media, journalism on religioin or even as banal religion.

\section{SMS Tauhiid as mediatized religion: a case study}

SMS Tauhiid is one of many examples cases of religious practice that was born as the implications of the development of information and communication technology. This SMS-based religious message services operated by Pesantren Daarut Tauhiid Bandung, West Java and was initiated by KH Abdullah Gymnastiar or well-known as Aa Gym, the leader of the Pesantren and also one of most popular religious figures in Indonesia. As a product of technology, SMS Tauhiid has promises that people could access tausiah (religious messages) anytime and anywhere. SMS Tauhiid is a "lived religion" since it manifests in daily life and indicated by the involvement of aspects; first, holy book or other religious texts as a reference about ideal life which acts as the content of SMS Tauhiid. Secondly, its contain activities in which people relate to religion symbolically. Third, its imply the involvement of numerous people to bound in the domain of religion.

Since its emergence, SMS Tauhiid claimed as SMS-based religious message services since its content is more focused on religious messages. As religious content services, SMS Tauhiid referring to the verses of the Quran or hadith and Aa Gym's advices as religious leaders. Nevertheless, religious messages presented in SMS Tauhiid contents are more emphasis on the establishment of Islamic values that are more spiritual-universal and entirely delivered in similar style to the Aa Gym's oral communication style. Here are some examples of SMS Tauhiid contents; 
Aagym: Sahabat, Berbeda pendapat adalah hal yang lumrah, namun bila penuh dengan amarah, bukn lagi membela pendapatnya, namun membela nafsunya.

Aagym: My dearest friend, different opinions are commonplace, but when filled with anger, it is not defended its opinion anymore, but defended the lust.

Aagym: Shbtku, Semakin mampu mengendalikan amarah, semakin jernih dan jelas akal sehat mencari/menemukan solusi.

Aagym: My dearest friend, the more you able to control your anger, the more clear and obvious of your commonsense to find a solution.

Smstauhiid: Sesungguhnya Alloh mencintai orang2 yang bersabar (QS 3: 146).

Smstauhiid: Surely Allah loves the steadfast (QS 3: 146)

Smstauhiid: Boleh jadi engkau tak suka padahal baik menurut Alloh bagimu (QS 2: 216).

Smstauhiid: But perhaps you hate a thing and it is good for you (QS 2: 216)

Smstauhiid: Rosululloh saw. bersabda: "Mudahkanlah, jangan mempersulit. Dan jadikan suasana yang bahagia, jangan menegangkan" (HR Muslim).

Smstauhiid: Rasulullah saw. said: "make it easy, do not complicate. And build a happy atmosphere, do not tense" (H.R. Muslim).

Smstauhiid: Rosulullah saw. bersabda: "3 (tiga) hal yang merupakan pundipundi kebaikan: 1. Merahasikan derita; 2. Merahasikan musibah; 3. Merahasiakan sedekah" (HR Baihaqi).

Smstauhiid: Rasulullah saw. said: "three things that the bunch of kindness: 1 . Keeping suffering secretly; 2 . Keeping disavantage secretly; 3. Keeping alms secretly" (H.R. Baihaqi). 
In general, the content of SMS Tauhiid show different patterns with religious messages in traditional context that is more doctrinaire and textual. This implies that religious values appear in Tauhiid SMS is more practical rather than formal. Is more self-help rather than dogmatic. One common feature of the religious content in SMS Tauhiid is the style and "feel" of Aa Gym's words who is known as a sophisticated preacher, is more therapeutic, even when the content is the passage of the Qur'anic verses or hadith. ${ }^{33}$

At the user level, the self-help character of SMS Tauhiid perceived as useful to improve their spiritual quality. Through the short religious messages and in persuasive style, they are reminded to engage with religious teachings. In other words, SMS Tauhiid has become a "religious preacher." As a self-help religion, SMS Tauhiid also able to broaden the customers' view about religion. These phenomena indicate SMS Tauhiid as one of mediated religious expression that potentially becomes mediatization of religion.

The phenomenon of mediatization of religion more apparent when SMS Tauhiid transformed into institution that is indicated by the transformation of SMS Tauhiid as medium of religious information into institution that distributes religious messages that were almost out of control from Aa Gym. As institution, SMS Tauhiid has become more independent and operates with media logics whether technically or institutionally.

Technical logics of later SMS Tauhiid such as; character limitations of the content, hardware and software, and regulations. Meanwhile, the

${ }^{33}$ Long before SMS Tauhiid project launched, Aa Gym has been well-known as a popular Islamic preacher by his modest and oral communication style. In addition, he was also famous with some simple jargons for Indonesian Muslim which later published in some his books. One of his most famous jargon is $3 \mathrm{M}$ or Mulai dari hal-hal terkecil (begin with the little things), Mulai dari diri sendiri (begin with yourself), dan Mulai dari sekarang (begin from now). 
technology used to deliver the SMS contents was done with SMS Broadcast technology that enables a message sent to many different destinations in a single shipment. Also, the regulation has a significant influence on how the SMS Tauhiid works. It should be noted that one important factor that led to SMS Tauhiid is free is a strategic effort in utilizing of the offers thousands of free SMS by some operators. However, since June 1, 2012 when Indonesian government removed the free SMS crossoperator, SMS Tauhiid crew adapted regulation by increasing the number of the sender's number. In this way SMS Tauhiid can survive even have to take risky actions which later anticipated by using keywords for each content, means, at the beginning of any content, they put words 'aagym' and 'smstauhiid.'

As autonomous institutions SMS Tauhiid has affected to increasing number of crew which implies increasing operational costs, while their services is a free service which implies the lack of income. Furthermore, this phenomenon is further stage of mediatization where religion is not only accommodate and adapt the media logics, but also to internalize the media logics in religious practices. The strengthening of media logics has not only changed the content technically through the use of abbreviations, but also substantially through the presence of non-religious content.

With similar pattern and how religious content works, non-religious content also appear as part of the 'tausiah' shown through the use of the same keywords, namely 'aagym' and 'smstauhiid'. In general, non-religious content can be categorized into three major groups, they are; general information, personal agenda of Aa Gym and product information that are delivered entirely as 'tausiah' in SMS Tauhiid, as can be seen in the following content, 
Smstauhiid: Pesantren kilat liburan bersama Daarut Tauhiid untuk SD, SMP ES SMA, 30 Juni-03 Juli 2013. INFO: 0222008013/085722915176/ 081221175656/0811246519

This content used the keyword 'smstauhiid' to inform the activity organized by Pesantren Daarut Tauhiid. Although the activity a religious one, but this content is irrelevant as tausiah because it does not refer to text or religious figures. In another example, the content was also found to contain about an invitation to make a donation, as can be seen in the following content,

Smstauhiid: untk shbt2, yg ingin mmbantu dakwah smstauhiid bs via rek MANDIRI 132.00.30303052 An.SMSTauhiid/via transfer plsa 087825252626/082130303038 smg brtmbh berkah rizkinya

Still using the 'smstauhiid' keyword, the content above invites customers to donate. Furthermore, non-religious content in SMS Tauhiid is also contains the agenda of the Aa Gym. This content does not just appear by using the keyword 'smstauhiid', but also by using the keyword 'aagym'. In contrast to the content of information using the keyword 'smstauhiid', content with the keyword 'aagym' more likely an information of Aa Gym's activities personally as can be seen in the following content,

Aagym: apakabar shbtku, aa masih di sydney smp besok pagi, skarang ada pelatihan manajemen qolbu, ikhtiar agar hati bersih, $k r n$ hati adalah raja

As can be seen, the above content is about to publish the Aa Gym's activity personally and precisely with the prefix "aagym", as if this content is a diary of Aa Gym intended to be consumed by SMS Tauhiid subscribers. Then, exactly the next day SMS Tauhiid content sent the information of Aa Gym's arrival in Indonesia,

Aagym: Alhamdulillah sudah kembali ke tanah air, shbtku di bdg dan skitar, datang ke DT bdg ya, bada magrib syekh ali, aa bada isya live mqfm 1027 
Perhaps the emergence of information about Aa Gym's personal life is a strategy in establish the emotional closeness with the congregation as Aa Gym is often express his life experiences in his a religious lecture so it is not surprising if this pattern also occurs in the SMS Tauhiid. However, some of this content implies that audience of SMS Tauhiid are not only received religious messages as tausiah, but also let them to receive the content outside of the the tausiah context.

Therefore, in general it can be said that SMS Tauhiid content have a specific direction of development so the content can be categorized into two main categories, namely the religious and non-religious content. Religious content represented the idealism of the early establishment of SMS Tauhiid services as an SMS service with reference to the figures and religious texts. Meanwhile, non-religious content that came later are the implications of changes in Tauhiid SMS status as an autonomous institution that runs the media logics.

Obviously that the potential development of the content are more in non-religious contents. The development of various contents describe mediatization practices that characterized by the adaptation, accommodation and internalization of media logics in SMS Tauhiid which initially serve the religious interests. Therefore, the appearance of non-religious content on SMS Tauhiid depicting the battle between religion and media logics.

This phenomenon is important because Aa Gym said that SMS Tauhiid is only contains tausiah that refer to religious texts and nothing to do with economic interests. Therefore, it can be said that the emergence of non-religious content is indicating the the strengthening of media logic by the increasing of crew authority in determining the content. Theoretically, these are the act of adaptation and internalization of media logic that also indicates a reduced the role of Aa Gym's role as religious 
information source. The competition between the religious interests against media logics can be seen in Fig.1, which shows a shift in roles from each other.

Fig. 1. The practice of mediatization of religion in SMS Tauhiid

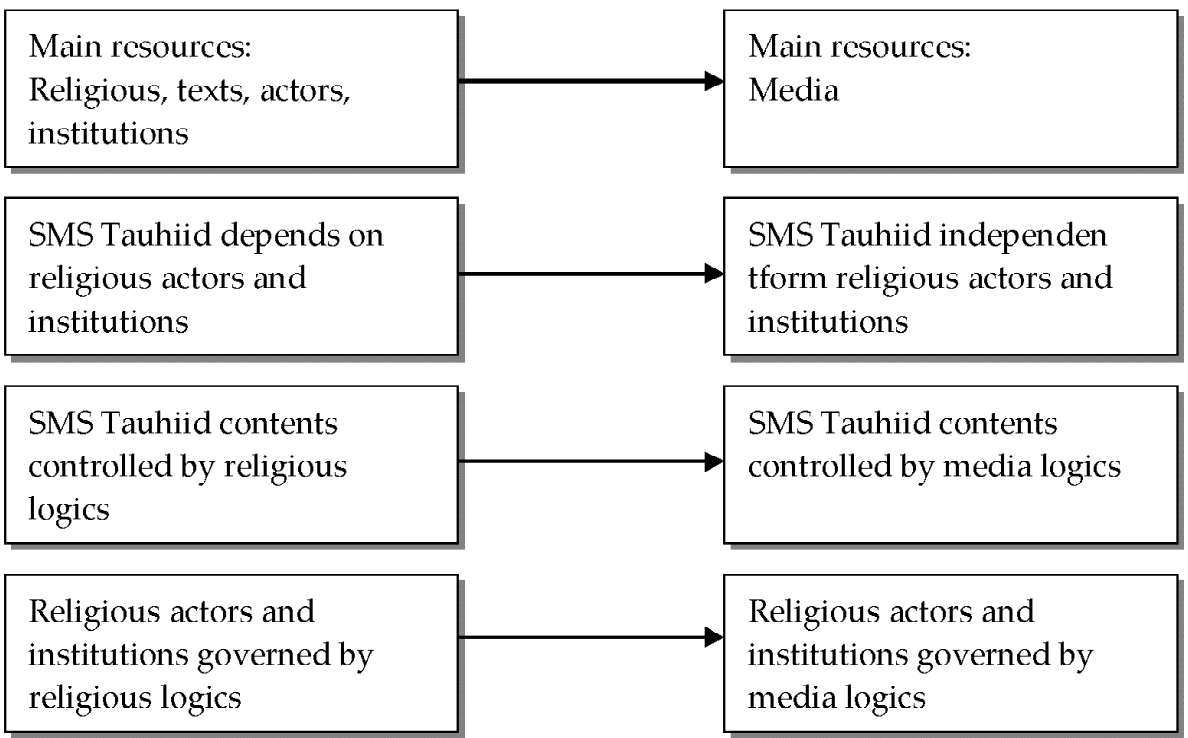

Regardless of the impressions of the users, the change of SMS Tauhiid content has demonstrated two important symptom of mediatization of religion. First, SMS Tauhiid has evolved into autonomous institution and begin to lose of control by Aa Gym as religious leaders who previously used the SMS Tauhiid to serve as the medium in religious communication. Secondly, when it emerged as autonomous institution, SMS Tauhiid increasingly independent in determining the content that was originally are Aa Gym's authority as a religious figure. 


\section{Conclusion}

At least, there are two important implications of the practice of religion in the case of SMS mediatisasi Tauhiid. First, religious messages are presented to be more self-help and therapeutic; second, there was a shift of Aa Gym's role as a source of religious content as well as the originator SMS Tauhiid. However, these implications have different character. The first implication namely SMS Tauhiid as self-help religion is characterized by a reflective and therapeutic style which presented in a very short content.

As technology, SMS has certain limitations that are technical and sometimes require users to adjust with. Therefore, the nature of self-help of SMS Tauhiid basically is an effort of adjustment of religious messages to the limitations of SMS itself. As emphasized by Goggin ${ }^{34}$ that cellular phones are "central cultural technology" that shape our daily behavior in his own way, including in spreading religious messages.

Limitations of SMS character number is not something ahistorical. Behind its limitation, there is always actors who are not only human but also non-human actors. This can be understood by using the perspective of actor-nework theory that rethinking the binary opposition between machine and human to understand that both human and the technology-in this case, SMS and mobile phone-are always try to adjust to each other. On the one hand, SMS technology trying to expand the capabilities to serve human better as a modification and on the other hand, human was trying to adjust the nature and limitations of SMS technology, for example in terms of the limited number of SMS characters.

The second implication in Tauhiid SMS phenomenon is a shift in the role of religious leaders as a source of content. This is shown by the ap-

\footnotetext{
${ }^{34}$ G. Goggin, Cell Phone Culture: Mobile Technology in Everyday Life, London: Routledge, 2006, 2.
} 
pearance of non-religious content in the service with the same jargon. The presence of non-religious contents described another practice aside of efforts to spread the religious message and slightly has obscured the role of Aa Gym as religious leaders who initially aimed to use technology for religious interest.

Therefore in general it can be said that SMS Tauhiid is one form of imagined religion in the context of media culture. People want religion to adjust the development of the media so religion does not lose access to the audience. The same logic used by the religious actors and preachers by using the media for their interest in transmitting religious messages. As the spiritual imagination of modern society, SMS Tauhiid has reflected some phenomena. First, SMS Tauhiid born to use the technology for the religious sake so SMS was assumed as an agent that serves the interest of religious preaching.

Second, in the early days of its establishment, SMS Tauhiid reflected the changing orientation of Aa Gym in his teachings that focused more on the teachings of Tauhiid that more universal. However, later it was published in the SMS content Tauhiid not only contains the teachings of monotheism, but also other information that is actually not related to the teachings of monotheism.

Third, by applying the term "tauhiid" (Arabic: tawhid)-that is an Islamic-related word-to the "SMS" term representing media technology, SMS Tauhiid is an imagination about how technology should be used for religious purposes. Nevertheless in reality, the accommodation of the media logics performed by SMS Tauhiid crews actually turned out to experience the simplification and reduction of religious meaning caused by the characters limited on SMS that encourages crews to 'simplify' the content in shorter way so it is more self-help style. 
Fourth, SMS Tauhiid has imagined as the omnipresence nature of religion, including in the areas of the economy. At the same time, it is precisely contrary to the ideals Aa Gym as the originator of SMS Tauhiid. Not only that, Aa Gym as having the authority of religious information later positioned and regulated by the logic of the media.

\section{Bibliography}

Barendegt, B. and Pertierra, R., "Supernatural Mobile Communication in the Philippines and Indonesia" in James E. Katz. Handbook of Mobile Communication Studies. Massachusetts: MIT Press, 2008.

Bunt, G.R., "Surfing the App Souq: Islamic Applications for Mobile Devices", in CyberOrient, Vol. 4, Issue 1 (2010).

Christoffersen, M., "Mobile Telephony in Denmark: From Fishermen to Businessmen: Social Aspects of the NMT-System", in Les Usages Sociaux de la Téléphonie Mobile en Scandinavie, CNET/IDATE seminar, Institut Finlandais, Paris, 30 January, 1992.

De Gournay, C., Tarrius, A., and Missaoui, L., "The Structure of Communication Usage of Travelling Managers", in Haddon, L. (ed.). Communications on the Move: The Experience of Mobile Telephony in the 1990s COST 248 Report. Farsta, Sweden: Telia AB., 1997.

Du Gay et. al. Doing Cultural Studies: The Story of the Sony Walkman. London: SAGE Publications, 1997.

Fortunati, L., "The Ambiguous Image of the Mobile Phone", in Haddon, L. (ed.). Communications on the Move: The Experience of Mobile Telephony in the 1990s COST 248 Report. Farsta, Sweden: Telia, 1977.

Geser, H., "Towards a Sociological Theory of the Mobile Phone", Sociology in Switzerland: Sociology of the Mobile Phone, online publication, Zürich, May 2004 (Release 3.0) <http://socio.ch/mobile/ t_geser1.pdf>, 2004.

Goggin, G. Cell Phone Culture: Mobile Technology in Everyday Life. London: Routledge, 2006.

Haddon, L. Old and New Forms of Communication: E-mail and Mobile Telephony: A report for British Telecom. Martlesham: British Telecom, 2000.

Hjarvard, S., "The Mediatisation of Religion: Theorising religion, media and social change", Culture and Religion, Vol 12, No. 2 (June, 2011): 21-22. 
Hoover, S.M. and Clark, L.S. (ed.). Practicing Religion in the Age of the Media: Explorations in Media, Religion, and Culture. New York: Columbia University Press, 2002.

Hoover, S.M. Religion in the Media Age. New York: Routledge, 2006.

Horsfield, P., "Media" in David Morgan (ed.). Keywords in Religion, Media and Culture. London: Routledge, 2008.

Ito, et al., "Mobile phones, Japanese youth and the re-placement of social contact", in Ling R. and Pedersen P.E. (ed.). Mobile Communication: Renegotiation of the Social Sphere. London: Springer, 2005.

Katz, J. and Aakhus, M. (ed.). Perpetual Contact: Mobile Communication, Private Talk, Public Performance. Cambridge: Cambridge University Press, 2004.

Kellner, D., Budaya Media: Cultural Studies, Identitas dan Politik antara Modern dan Postmodern. Translated into Bahasa Indonesia by Galih Bondan Rambatan. Yogyakarta: Jalasutra, 2010.

Krotz, F., "Mediatization: A Concept with Which to Grasp Media and Societal Change", in Knut Lundby. Mediatization: Concept, Changes, Consequences. New York: Peter Lang Publishing, 2009.

Ling, R. and Yttri, B., "Hyper-coordination via mobile phones in Norway", in Katz, J. and Aakhus, R. (eds.). Perpetual Contact: Mobile Communication, Private Talk, Public Performance. Cambridge: Cambridge University Press, 2004.

Ling, R. The Mobile Connection: The Cell Phone's Impact on Society. San Francisco: Elsevier, 2004.

Ling, R. New Tech, New Ties: How Mobile Communication is Reshaping Social Cohesion. Cambridge, Massachusetts: MIT Press, 2008.

Martin-Barbero, J. Communication, Culture and Hegemony: From Media to Mediations. Translated by Elizabeth Fox and Robert A. White. London: SAGE Publications, 1993.

Petersen, L.N., "Renegotiating religious imaginations through transformations of "banal religion" in Supernatural", Transformative Works and Cultures, No. 4 (2010).

Petersen, L.N., "Understanding superpowers in contemporary televison fiction”, Northern Lights: Film and Media Studies Yearbook, Vol. 6 (2011): 91106.

Rakow, L., and Navarro, V., "Remote Mothering and the Parallel Shift: Women Meet the Cellular Phone", in Critical Studies in Mass Communication, 10/ 2 (1993). 
IJIMS, Indonesian Journal of Islam and Muslim Societies, Volume 5, Number 2, December 2015: 231-254

Rao M. and Desai, M., "Boom in India: Mobile Media and Social Consequences", in James E. Katz. Handbook of Mobile Communication Studies. Massachusetts: MIT Press, 2008.

Silverstone, R. Media and Morality: On the Rise of the Mediapolis. Cambridge: Polity Press, 2007.

Suryanto, "Iklan dan Komodifikasi Agama", Tesis, Yogyakarta: Universitas Gadjah Mada, 2011.

Wood, J., Cellphones on the Clapham Omnibus: The Lead-Up to a Cellular Mass Market. SPRU CICT Report No. 11, University of Sussex: Falmer, November, 1993. 